\title{
Effects of terrorism and political instability on tourist behavior: 2016 conflicts in Turkey
}

\section{Onur KOYUNCU \\ Hacettepe University, Turkey}

\begin{abstract}
:
Aim: This article investigates the effects of two attacks and a failed coup attempt during 2016 on the tourist behavior. Foreign tourist data for the 2003-2019 period is analyzed to observe irregularities in Turkey's national tourism income.

Design / Research methods: Linear regression, multivariate regression and regression based static forecasting methods are applied for modeling the relationships. These models are supported with statistical tests.

Conclusions / findings: Results on this study are in accordance with the current literature in the sense that conflicts in 2016 caused a shift in tourist behavior which in turn impaired the tourism industry in Turkey. Repercussions did not endure longer than expected and Turkish tourism recovered rapidly, only facing a serious loss due to the shift in tourism demand trend.

Originality / value of the article: This study makes an addition to the terror and tourism literature, especially for the Mediterranean region and specifically for Turkey both of which are among the most popular tourist destinations worldwide. The aftermath of attacks and the coup attempt in Turkey during 2016 have not been researched before. The data and the outcomes presented sufficient evidence to infer on this issue.
\end{abstract}

Keywords: Terrorism, Mediterranean tourism, Turkey, Economic impact, Forecast, Demand JEL: C12, C22, C53, E71

Contact details: Onur Koyuncu, Department of Business Administration, Faculty of Economics and Administrative Sciences, Hacettepe University, Turkey. E-mail: okoyuncu@ hacettepe.edu.tr Received: 10.01.2020, Revised: 12.02.2020, Accepted: 13.04.2020 doi: http://dx.doi.org/10.29015/cerem.866 


\section{Introduction}

Tourism is an ever growing global industry. It's an important source of income for popular destinations, contributing positively to national GDP, employment rates, foreign direct investment and growth. For the developing countries this positive effect becomes more pronounced. Mediterranean region exemplifies this context ideally, harboring both developed and developing countries with indispensable tourism incomes. To name a few, Turkey, Israel, Greece, Egypt and Lebanon all promise similar benefits to the international tourists; impressive beaches, nature and historical sites at enticing prices. These mentioned countries alone make up for a total share of $5.1 \%$ of average worldwide tourism generated revenues during the last decade (including 2010-2017, calculated from the World Bank statistics as is the case in the remainder of this section).

Being the focus of this study, the tourism incomes play a significant role on Turkish economy. As a gateway between Europe and Asia, Turkey is one of the major destinations of tourists. Turkey shares borders with continental Europe, Caucasian region and the Middle Eastern region. In terms of proximity and prices, it's welcoming for visitors to enjoy both history and nature at the same time. Turkey has an average share of $2.39 \%$ worldwide tourism revenues in the last decade. The revenue shares of Turkey are $3.8 \%$ among the OECD countries, $13.7 \%$ among the European countries on the Mediterranean coast and $64.5 \%$ among the Levantine coast during the same period. Turkey's average tourism revenue share in the last decade is $11.8 \%$ among all of the Mediterranean countries (excluding Libya which lacked data). The share of tourism revenues in Turkey's GDP is 3.35\% between 2010 and 2018. These figures show how important tourism is for Turkey's economy and Turkey is for international tourism.

Naturally, countries like Turkey thrive to sustain and improve their tourism incomes. The link between tourism and economic growth has been documented in the literature as being positive (Brida et al. 2016). A vast majority of approximately 100 published articles were in favor of the hypothesis that suggests tourism drives growth. On the other hand, one of the most important factors affecting tourist choice and behavior is safety. Terrorism and conflicts are among the strongest nominees for 
affecting the tourist behavior negatively with evidence from numerous articles in the literature discussed in the next section. These two suggestions imply that terrorism and conflict not only endanger the national tourism revenues but also have an impact on national economic growth directly (Gupta et al. 2004) and via the decline on tourism revenues (Öcal, Yildirim 2010; Afonso-Rodriguez 2017).

Middle Eastern region has always been in constant conflict throughout the ages. Since the era of Sumerians and Akkadians, conflicts, conquests and wars have been commonplace. During the recent history, Turkey had its share of all types of conflicts; political, civil, military and by means of armed terrorism. As most notable milestones, 1960s were the times of leftist uprisings, 1970s saw the terror acts of ASALA (Armenian Secret Army for the Liberation of Armenia) and 1980s witnessed the birth of jihadist terrorism in the form of Turkish Hezbollah and the separatist Kurdish movements in the form of PKK (Kurdistan Workers' Party). There have been many riots and pogroms with notable examples of Thrace (1934), Istanbul (1955), Maras and Malatya (1978), Corum (1980) and Sivas (1993). Turkey faced two coups (1960 and 1980) during which there was a huge amount of left-wing and right-wing clash causing thousands of casualties. A military memorandum took place in 1971, along with a post modern military memorandum (1997), an e-memorandum (2007) and a failed coup attempt (2016). During the last decade, the newest notable additions to the list above have been ISIS (Islamic State of Iraq and Syria) on the jihadist side and FETO (Fethullahist Terror Organization). The latter is a religious cult-like structure judged to have constructed a parallel organization, penetrating the key positions in bureaucratic and judicial institutions, and in military and police forces, in order to intervene and take over the government via the 15 July failed coup attempt. A well structured history of terrorism in Turkey before 2010 is summarized by Öcal and Yildirim (2010).

For Turkey, a country which does not have the luxury to risk its tourism incomes, 2016 was an exceptionally disastrous year. There were 16 suicide bomber attacks from PKK, TAK (Kurdistan Freedom Hawks) and ISIS causing 320 deaths. The failed coup attempt on 15 July billed 240 losses and a nationwide outbreak of accusations and arrestments under the emergency state. Also Turkish military forces initiated the land operations for the safety of southern borders in northern Syria. It was not a year to be 
forgotten easily and it is reasonable to expect this huge accumulation of terrorist activity and political instability to highly impact the tourism potential for Turkey negatively. The repercussions of 2016 conflicts have not been analyzed yet as we know of it. Perles-Ribes et al. (2016) made a note on it, stating that this period may compromise their conclusions which present Turkey as a winner in terms of tourism based on the Arab uprisings and the effect of 2016 on this interpretation needs to be researched. As we discuss in section 3, the 15-period data looks sufficient to evaluate how tourism in Turkey coped with such a disadvantageous period.

The organization of the rest of the study is as follows. In the next section we provide a brief literature review, focusing mostly on tourism in Turkey and the Mediterranean region. Then we present the data sources and the hypothesis of the study. The following section shows the analysis and the empirical results. Finally we conclude with a summary of the research, findings and their implications.

\section{Literature review}

Research about the effects of local unrest, terrorism and political instability on tourism took off during the 1990s when the barriers for traveling abroad relaxed, the global media became easier to access and people were more aware of the events taking place in their desired destinations. Although the history of the events stretch further back, by this time all types of unrest and conflicts including terrorist attacks, civil wars, shootings, coups and such became more visible. In the 1980s, Turkey had faced a coup at the start of the decade and the terror acts of Kurdish separatist groups and radical Islamic groups had just started. Israel had conflicts with Palestine and Lebanon with other countries such as Syria and Iran joining the crises on and off. Iraq and Iran had engaged in war. Pakistan and Afghanistan were in conflict and the overall Middle Eastern region had no rest with minor changes in its intrinsic dynamics to this day. In Europe, ETA (Basque Homeland and Liberty) was active in Spain whereas the acts of counter GAL (Antiterrorist Liberation Groups) stretched to France. IRA (Irish Republican Army) was also active in Ireland and UK. Popular tourist destinations like Italy, France, Egypt and Greece also faced serious terrorist attacks. Since then acts of 
terrorism continued throughout the world. As a matter of course, the focus of related scientific research was at large on terrorism and war.

Enders et al. (1992) were one of the first to point the negative relationship between terrorism and tourism where they state that increasing acts of terrorism resulted in a decline of revenues gathered from tourism. From here onwards, our take on literature review will bias on Turkey and tourism related competitors of Turkey.

In the Mediterranean region, the negative effect stated by Enders et al. (1992) was confirmed for the 1991-2000 period with an added detection of cross-country demand shift between Greece, Israel and Turkey (Drakos, Kutan 2003). They also state that intensity of casualties and geographic dispersion have an effect on tourism and the acts of terrorism shall be decomposed which is one of the motivations of this study. Llorca-Vivero (2008) verified the adverse effect of declined tourism flows, especially as being more accented for developing countries like Turkey, in their study analyzing flows from G-7 countries to 134 destination countries.

In a study investigating how the macroeconomic parameters of 22 (including Turkey) low to upper-middle income countries were affected by armed conflict, Gupta et al. (2004) found that armed conflict has a negative impact on growth, inflation and governmental spending on defense at a level that risks macroeconomic stability. The effect on growth was stated to be both indirect via defense expenditures and also direct. Yaya (2009) also studied the economic effects of terrorism on tourism, taking Turkey into focus, and found a small decline in tourism industry growth but a large decline on tourist volume. He pointed to a decline of 6 million tourists in a 9-year period and a 700 million USD bill corresponding to costs caused by terrorism for 2006 alone. In another study, Öcal and Yildirim (2010) reported a negative effect of terrorism on overall growth in Turkey in which they support the country focused approach as opposed to cross-country analysis on grounds of risks of heterogeneity. The effect is stated to be more pronounced in the Eastern and South Eastern regions where the terror acts are relatively concentrated. Their suggestion on behavior heterogeneity was later verified by Seabra et al. (2013) at least based on the tourist segmentation perspective.

Feridun (2011) investigated the 1986-2006 time period for Turkey, the period where PKK was most active in terms of armed terrorist activities, and found a negative 
causal effect of terrorism on tourism while pointing to a long-run equilibrium level relationship between the two.

Alvarez and Campo (2014) concluded that the image of Israel and the Turkish people's intentions to visit Israel were negatively affected after the Mavi Marmara conflict between the two countries. To pinpoint the importance of political conflicts, Saha and Yap (2014) analyzed 139 countries to find that political volatility and conflicts play a more important role than one-off terrorist attacks as far as the national tourism industries are concerned.

In an extensive study focusing on 1977-2014 time frame, Afonso-Rodriguez (2017) found evidence of negative effects of terrorist attacks on Turkish tourism industry and economic growth. He states a decline up to $10 \%$ is plausible in real GDP when the severity of attacks are over a certain threshold.

Perles-Ribes et al. (2018) analyzed the effect of Arab uprisings to the Mediterranean tourism to reveal a negative effect in the countries of conflict (mainly Tunisia and Egypt) and a spillover to alternative destinations (Turkey and Morocco). They also noted a postscript about the conflicts in Turkey during 2016 as a cause of uncertainty which is another motivational point for this study. In another recent Mediterranean cross-country analysis, Bassil et al. (2019) studied the tourism terrorism relationship and the spillover effect between Turkey, Lebanon and Israel. According to them, tourism demand for Turkey and Israel increases when Lebanon faces terror acts whereas Turkey or Israel face a decline when terrorism acts take place in the other country.

As an opposite evidence however, Liu and Pratt (2017) noted that there is no long run effect of terrorism on tourism ( 9 out of 95) and very small evidence of short run effect ( 25 out of 95 ) and yet the effect is rather dependent on political regime, income level and tourism intensity. Still there is sufficient evidence to conclude that terrorism has a significant negative impact on tourism and the geographically close alternative destinations benefit from the suffering country's misfortune. 


\section{Data and hypotheses}

For this study, the data sets used were obtained exclusively from Turkish Statistical Institute (http://www.turkstat.gov.tr/Start.do) and The World Bank statistics (https://data.worldbank.org) where noted, such as seen in sections 1 and 4.4. The analysis was based on quarterly reported tourism variables. Main variables utilized were the number of foreign visitors and the incomes generated from foreign visitors. Since the incomes and volumes are highly correlated, only tourism incomes were utilized. Tourism statistics of Turkey are presented threefold; in groups of foreign visitors, Turkish citizens resident abroad and Turkish citizens resident in Turkey. The third group was excluded from the study since the study focuses on the behavior of international tourists visiting Turkey. As for the remaining two groups, Figure 1 shows that the conflicts may have a possible effect on foreign visitors, but a similar reaction is even less than subtle for the Turkish citizens residing abroad. For this reason the scope of the study was limited to the foreign tourists visiting Turkey.

Figure 1. Number of foreign and Turkish resident international tourists visiting Turkey (in millions)

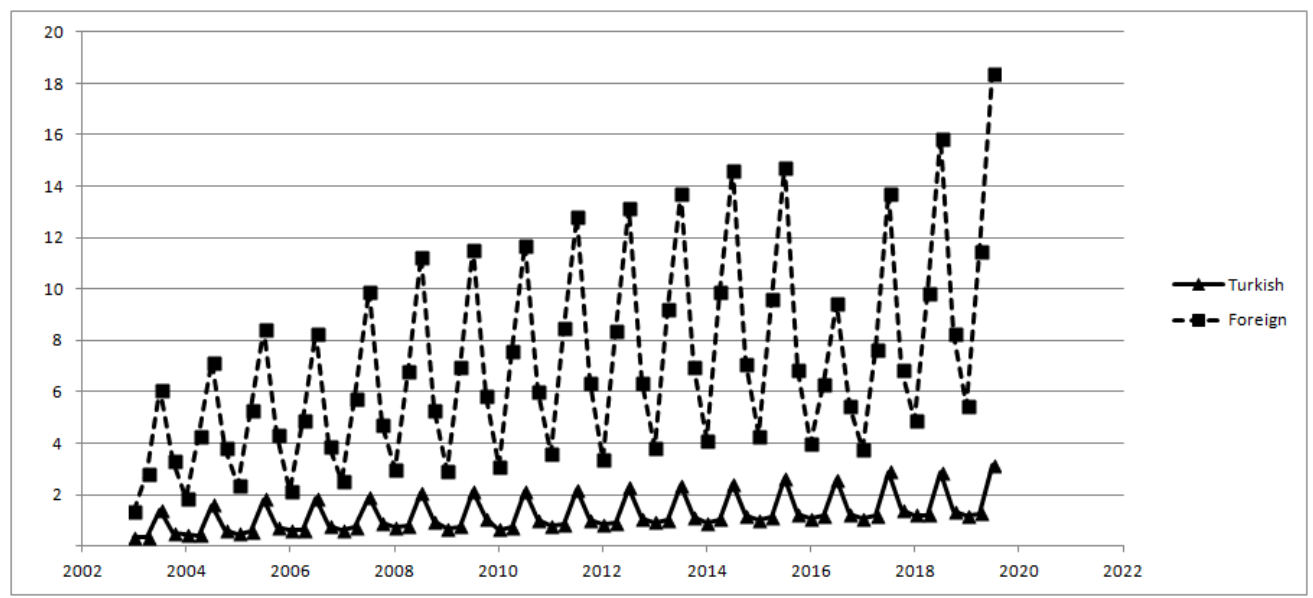

Source: Data processed from http://www.turkstat.gov.tr/Start.do by the author

It can be argued that Turkish citizens living abroad have a reason to visit their homelands and were either not affected by the conflicts or were reluctant to cancel 
their trips to Turkey. Foreign visitors on the other hand did not have such a motivation and had a chance to cancel or postpone their visits and converted to an alternative destination. Regardless of the reason, the practical consequence of this differentiation in behavior results in the fact that the study would not have benefited from analyzing the Turkish citizens living abroad and therefore this group was also discarded.

Figure 2. Annual visitors to Turkey from the top three source countries

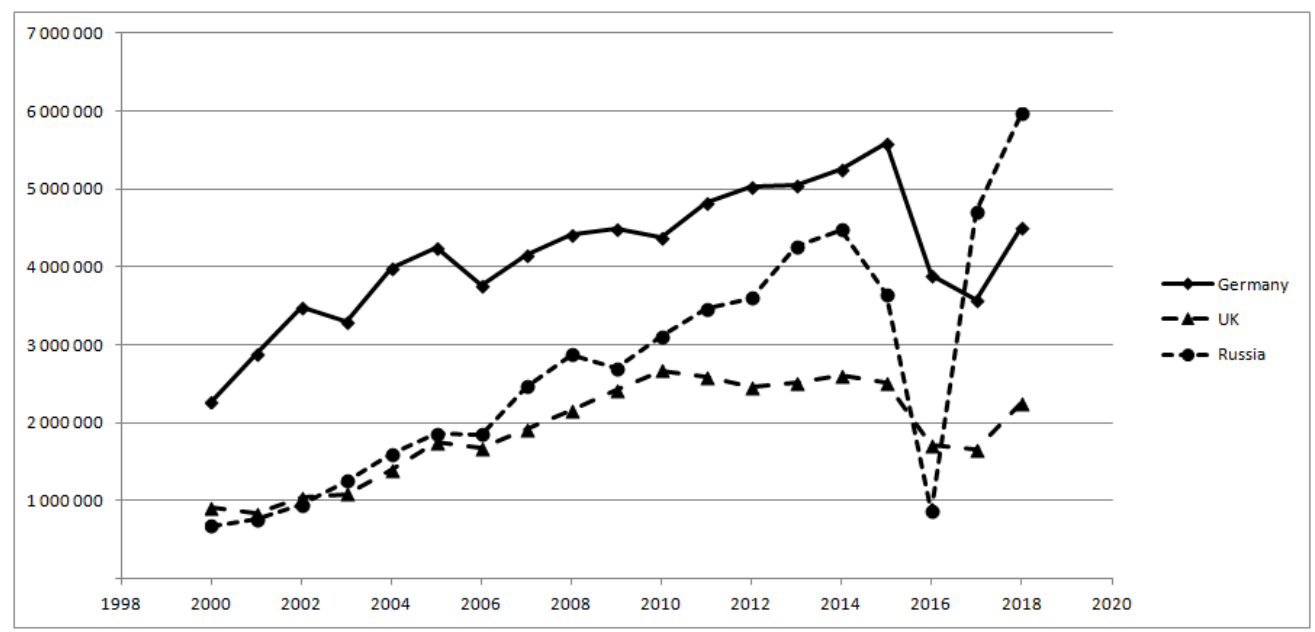

Source: Data processed from http://www.turkstat.gov.tr/Start.do by the author

Quickly glancing at the top three countries, a possible 2016 effect is observed clearer in Figure 2 which includes the German visitors with Turkish origins. Tourists of these countries mainly visit for holidays and consequently may have sacrificed (or picked an alternative destination) their plans due to a perceived safety risk. The next group of countries with two million or more visitors (Bulgaria, Georgia, Iran and Iraq) share borders with Turkey and the majority of tourists from these countries visit either daily or for weekends, are expected to be frequent visitors and to be familiar with conflicts in Turkey and thus were not included in the graph.

Foreign visitors show a very well structured demand pattern with an expected seasonality between the four quarters of the year displaying peaks in summer and troughs in winter periods and a general linear upward trend. However, a significant shift is observed during 2016 where the shift becomes most salient at the third quarter. 
This corresponds to the period including 12 January Istanbul attack with some lag and 28 June Istanbul airport attack and 15 July failed coup attempt. We expect these dates to be the most striking events of 2016 within the foreign tourists' perception. Based on this irregularity the following hypotheses were constructed:

- $\mathrm{H}_{1}$ : There is a structural change in tourism volume and national tourism incomes which could be attributed to the 2016 conflicts

- $\mathrm{H}_{2}$ : The 2016 conflicts had a significant negative effect on Turkey's tourism demand trend

- $\mathrm{H}_{3}$ : There is a negative shift of tourism trend caused by the 2016 conflicts

- $\mathrm{H}_{4}$ : The 2016 conflicts had a negative impact on Turkish economy

First hypothesis is tested threefold including a breakpoint test and multivariate regression. In the previous section, it was observed from the past research that potential insecurities based on safety would affect the tourist behavior negatively. Two attacks summing up to almost 300 casualties (51 total losses) and a coup attempt causing close to 2,000 casualties (240 losses) is capable of triggering a radical change in tourist opinions to reconsider their destinations along with a large number of attacks throughout the year.

Second hypothesis is investigated by statistically testing the linear trends before and after the start of conflicts. For the third hypothesis, static forecasts were carried out and the potential losses of tourism revenues are compared with Turkey's GDP and reserves.

\section{Empirical results}

\subsection{Structural change in tourist volume and respective revenue}

In order to verify the potential structural change caused by the conflicts, revenues generated from tourism were processed as a linear regression with respect to time as a first step. This regression yielded the linear model;

$$
R F_{i}=3,18 \mathrm{~m}+55,424 Q_{i}
$$


where $\mathrm{RF}_{\mathrm{i}}$ is the quarterly tourism revenues for period $\mathrm{i}$ and $\mathrm{Q}_{\mathrm{i}}$ is the incremental quarter index.

The reason for using a linear regression was to prepare a basis to carry out a structural break test. The chosen test is the popular breakpoint test offered by Chow (1960: 599-602). Results of the test proved that there was a structural change at a 95\% confidence level which are presented in Table 1. The sampling period chosen for the Chow test ends in 2016q1.

Table 1. Chow breakpoint test results for RF and VF

\begin{tabular}{|l|l|}
\hline \multicolumn{2}{|c|}{ Test for RF (2003q1-2016q1) } \\
\hline F-statistic (Prob.) & $5.43\left(0.007^{*}\right)$ \\
\hline Log Likelihood Ratio (Prob.) & $10.65\left(0.005^{*}\right)$ \\
\hline Wald Statistic (Prob.) & $10.86\left(0.004^{*}\right)$ \\
\hline
\end{tabular}

* Significant at $95 \%$ confidence level.

Figure 3. Seasonal difference regression and error plot (DRF)

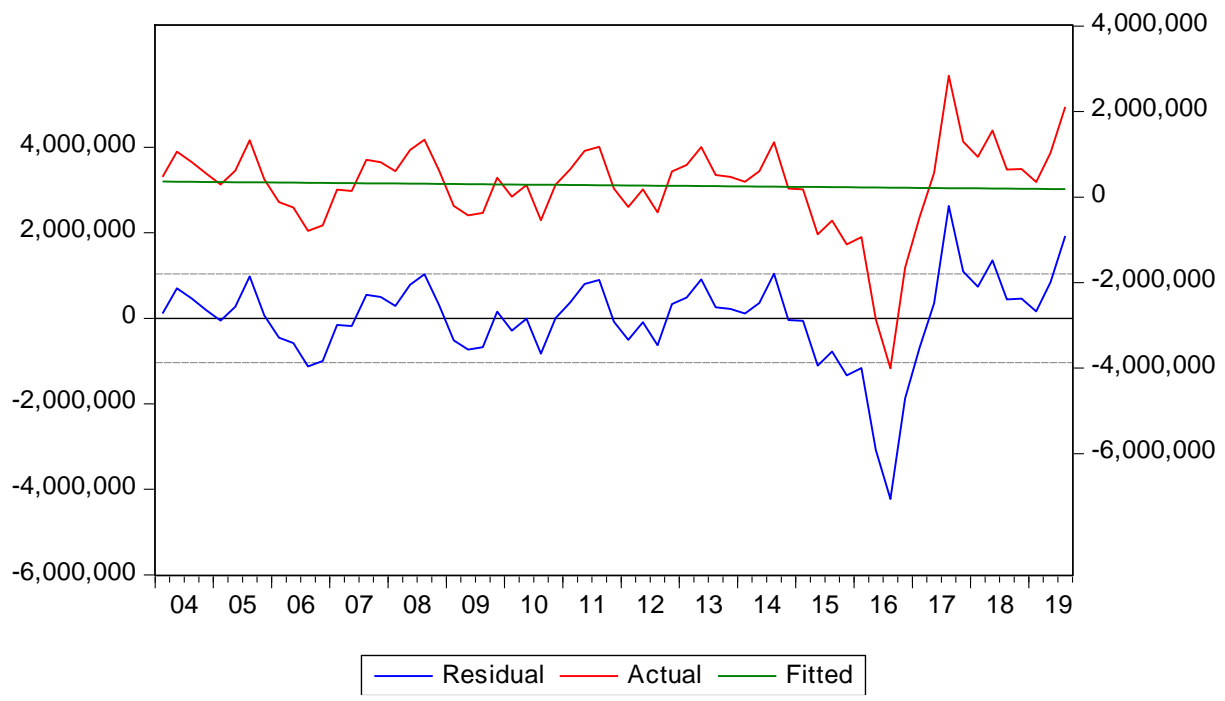

To make the structural break clearer, the four-period seasonal structured data set was transformed into a four-period ordinary difference data set. Such transformations are expected to provide nearly flat regressions with identically distributed residuals. 
The resulting transformed regression and respective residuals for the differenced variable DRF are shown in Figure 3. Figure 3 provides an alternative clear view of the sudden drop in 2016q3 in generated tourism revenues where either the failed coup attempt and 28 June attack received a sudden response or a 6-month lag effect of the 12 January attack is observed.

As a third check, a dummy variable (D) was created where it assumed values of zero for the sampling period in the Chow test and one otherwise. This variable was added to the previous linear regression as a second independent variable. Multivariable regression model is given below in equation (1). Outcomes are presented in Table 2.

$$
R F_{i}=\alpha+\beta_{1} Q_{i}+\beta_{2} D_{i}+\varepsilon_{i}
$$

\section{Table 2. Multivariable regression results}

\begin{tabular}{|l|c|c|}
\hline & RF regression with D & VF regression with D \\
\hline Intercept (Prob.) & $2,422,732\left(0.0001^{*}\right)$ & $3,294,358\left(0.0005^{*}\right)$ \\
\hline Quarter variable (Prob.) & $93,332\left(0.0000^{*}\right)$ & $130,196\left(0.0001^{*}\right)$ \\
\hline Dummy variable (Prob.) & $-2,435,636\left(0.0111^{*}\right)$ & $-2,196,303(0.1228)$ \\
\hline Adjusted R ${ }^{2}$ & 0.239 & 0.245 \\
\hline F-prob. & $0.000059^{*}$ & $0.000046^{*}$ \\
\hline
\end{tabular}

* Significant at $95 \%$ confidence level.

Multivariable regression results show that the dummy variable has a significant effect on the generated tourism revenues.

Hence, we conclude this subsection by stating that the first hypothesis was verified and the 2016 conflicts can be regarded as a factor, hindering the tourism potential and incomes of Turkey. It is apparent that foreign tourists visiting Turkey showed a tendency to cancel their trips after the first attack and during the quarter of the coup attempt and the second attack in targeting tourists during the same year in Istanbul due to safety concerns. 


\subsection{Trend change before and after the 2016 conflicts}

Next we investigate whether there was a change in tourist behavior portrayed by a change in trend before and after the conflicts. It was argued before that the visitors with Turkish origin showed no signs of desisting from travelling to Turkey. But this was not the case for foreign tourists. Due to the fact that armed conflict part of the coup attempt ended in a mere couple of days, and that the repercussions were mostly based on interrogations and investigations directed on discovering and apprehending the attempters with no observable threat on civilians, it is plausible to expect the tourism demand for Turkey to survive this incident unscathed. But as Perles-Ribes et al. (2019: 1826) stated, the repercussions of the two armed attacks involving tourists and the remaining local attacks could be huge and whether Turkish tourism industry would recover is yet to be analyzed.

Table 3. Tourism revenue trends before and after the conflicts

\begin{tabular}{|l|c|c|}
\hline & $\begin{array}{c}\text { Before the conflicts } \\
(\text { Model 2) }\end{array}$ & $\begin{array}{c}\text { Remaining periods } \\
\text { (Model 3) }\end{array}$ \\
\hline Constant variable (Prob.) & $2,572,178(0.0001 *)$ & $-14,477,505(0.0902)$ \\
\hline Quarter variable (Prob.) & $87,472\left(0.0000^{*}\right)$ & $338,495(0.0250 *)$ \\
\hline SE of Quarter variable & $19,677.73$ & $133,697.30$ \\
\hline $\mathrm{R}^{2}$ & 0.283 & 0.330 \\
\hline F-prob. & $0.000049^{*}$ & $0.025039^{*}$ \\
\hline
\end{tabular}

* Significant at 95\% confidence level.

For this purpose, the sample was split into two in a similar fashion as the previous subsection. Pre-conflict and the remaining period revenues were separately converted into linear regressions in order to test their slopes to see if the latter period has a significantly flatter slope. Since the significance for structural change was more apparent in generated revenues, we proceed with the remaining analysis with the RF variable. The outcomes of the two aforementioned regressions (labeled as models 2 and 3) are given in Table 3 and the matching graphs are presented in Figure 4. 


\section{Figure 4. Tourism revenues (in billion USD) before and after the conflicts}

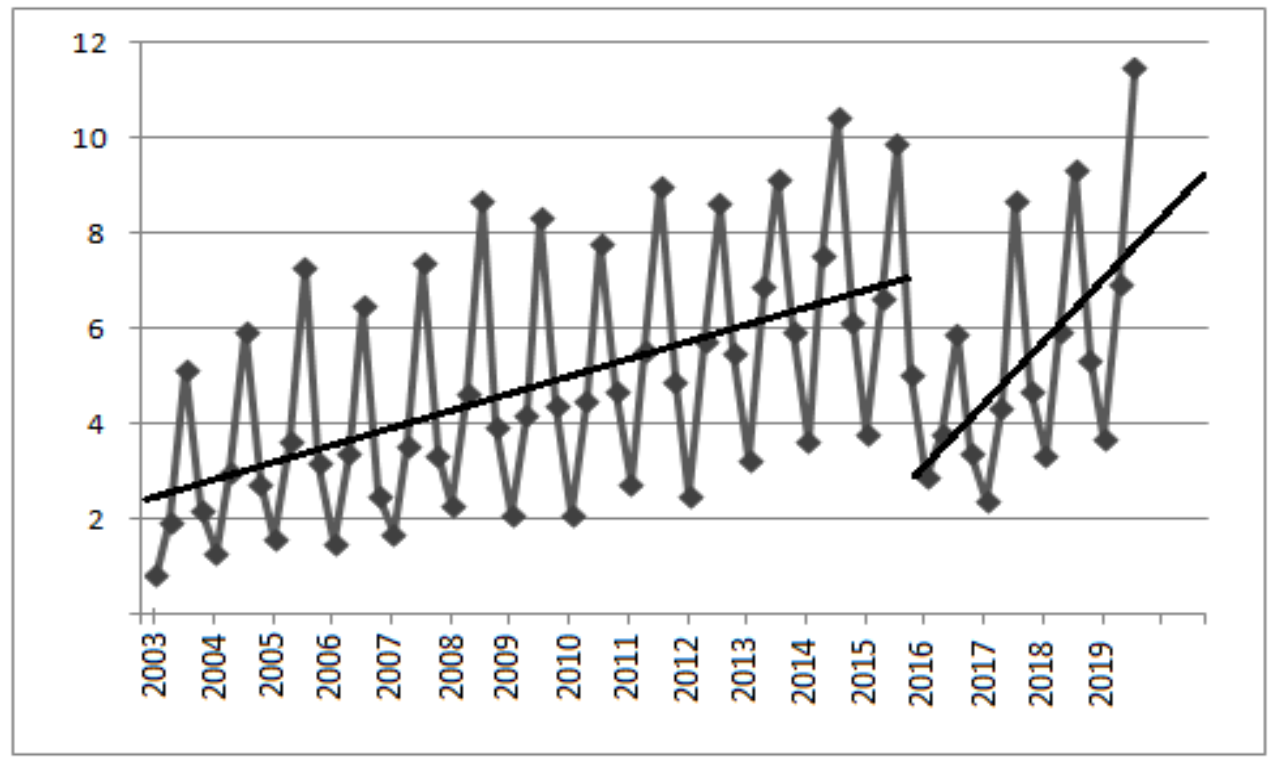

As is readily seen from Figure 4, the general trend changes after the conflicts with a sharper slope, denoting an overall increase in tourism revenues for Turkey. The change in trend shall be considered significant via testing. Such a test is offered by Paternoster et al. (1998: 862). Accordingly, the test statistic $\mathrm{Z}$ for the null hypothesis $H_{0}: \beta_{1} \geq \beta_{2}$ can be calculated from the regression outputs in Table 3:

$$
Z_{c a l}=\frac{\beta_{1}-\beta_{2}}{\sqrt{S E_{\beta_{1}}^{2}+S E_{\beta_{2}}^{2}}}=\frac{87,472-338,495}{\sqrt{19,677.73^{2}+133,697.30^{2}}}=-1.85754
$$

Resulting $\mathrm{Z}$ value has a p-value of 0.0316 , meaning a rejection of the null hypothesis at a $5 \%$ significance level. Therefore we conclude that after the first shocks, the general trend of tourism demand for Turkey was not negatively affected by the 2016 conflicts and Turkey actually recovered fairly quickly from such a hazardous period.

The main drivers of this recovery may be attributed to several factors. Firstly, the Turkish Lira devalued heavily against Euro and USD starting from October 2016 (possibly due to the coup attempt) until late 2018 whereas the exchange rates were mostly stable during the prior one year period. This, in turn might have lead to a 
boosted spending power for foreign tourists visiting Turkey. The economic instability in Turkey also acted as a driver which accented the country as a significantly more affordable tourist attraction. Secondly, Turkey started investing in international tourism advertising campaigns in the last decade. Thirdly, major companies contributed largely to the image of Turkey via sponsorships. Especially Turkish Airlines became a huge actor, most notably sponsoring F.C. Barcelona (2009-2015), EuroLeague (2010-2020) in Europe and advertising in the Super Bowl games since 2016 in the United States among many other sponsorships.

It must also be noted that two other direct tourism competitors of Turkey struggling with constant conflicts, namely Israel and Egypt, have experienced completely different scenarios. Israel has an almost linear monotonic increase in their tourism revenues while Egypt's tourism revenues went downhill after the Arab Spring in early 2011 and did not recover until 2016.

\subsection{Trend shift after the 2016 conflicts}

To effectively control a possible shift in Turkey's tourism demand due to the 2016 conflicts, this time we test the regression given in 4.2 for the intercepts. The null hypothesis $H_{0}: \alpha_{1} \geq \alpha_{2}$ will be tested. The t-test utilizes a pooled variance of the two intercepts from the regressions (Kleinbaum, Kupper 1978: 101-104) in the form given in equation (3);

$$
S_{\left(\alpha_{1}-\alpha_{2}\right)}^{2}=\left(\frac{S S E_{1}+S S E_{2}}{n_{1}+n_{2}-4}\right) x\left(\frac{1}{n_{1}}+\frac{1}{n_{2}}+\frac{\overline{R F}_{1}}{S S_{R F_{1}}}+\frac{\overline{R F}_{2}}{S S_{R F_{2}}}\right)
$$

So the test statistic (in million USD) becomes;

$$
t_{c a l}=\frac{\alpha_{1}-\alpha_{2}}{\sqrt{S_{\left(a_{1}-a_{2}\right)}^{2}}}=\frac{2.57-(-14.48)}{5.41}=3.15
$$

with a p-value of almost 1.00 , which leads to a rejection of the null hypothesis. Thus, we conclude that there has been a significant shift during 2016 and the tourism demand trend declined radically. 


\subsection{The economic repercussions for Turkey}

In this part we focus on a possible scenario where 2016 was a year with no significant conflicts affecting the tourist behavior negatively. In such a case, there would be two alternative expectations. First would be to expect the tourism revenues to follow the past trend and seasonal structure hereafter called the neutral model. Second one is rather more optimistic in which we expect the trend to be sharper upwards as was actually observed.

Therefore we propose two seasonally adjusted static forecasts for the two respective scenarios. Methodology is similar to Ferbar Tratar et al. (2016) but in a static manner without a Holt's or Winters' style dynamic adaptation. The main idea is to smooth the seasonal data via three-period equally weighted moving averages, applying a regression to the smoothed data, obtain the average seasonal factors from the regressed values and estimate the future revenues generated from foreign tourists with the seasonal factors in charge. The model described is given in equation (3) and is of the form;

$$
F C_{i}=\left(L+T x S R F_{i}\right) x S F_{i}
$$

where $\mathrm{FC}_{\mathrm{i}}$ is the forecast for $\mathrm{i}^{\text {th }}$ quarter, $\mathrm{L}$ and $\mathrm{T}$ are the intercept and slope of the linear structure, $\mathrm{SRF}_{\mathrm{i}}$ denotes the smoothed revenues and $\mathrm{SF}_{\mathrm{i}}$ denotes the multiplicative seasonal factor for repeating quarters given in $\bmod (4)$. The neutral model is derived from the period $2003-2015$ and the optimistic model from the steeper period of 2016 - 2019. Both then are used to estimate the 2016-2019 period tourism revenues in the absence of the conflicts. The forecasts are given in Table 4 and visualized in Figure 5.

\section{Table 4. Forecast outputs of the neutral and optimistic models}

\begin{tabular}{|l|c|c|}
\hline & Neutral model & Optimistic model \\
\hline $\mathrm{L}$ & $2,587,758.68$ & $3,375,395.16$ \\
\hline $\mathrm{T}$ & $84,879.54$ & $243,791.09$ \\
\hline $\mathrm{SF}_{1}$ & 0.467 & 0.622 \\
\hline $\mathrm{SF}_{2}$ & 0.966 & 0.985 \\
\hline $\mathrm{SF}_{3}$ & 1.685 & 1.583 \\
\hline $\mathrm{SF}_{4}$ & 0.839 & 0.841 \\
\hline In-sample MAPE & $9.7 \%$ & $6.1 \%$ \\
\hline
\end{tabular}


The forecasts returned fairly acceptable MAPEs, both under $10 \%$. Based on Figure 5, a revenue gap exists (between the dotted and straight lines) caused by the effect of 2016 conflicts on the behavior of foreign tourists visiting Turkey. We simply assume this gap as a potential loss of tourism incomes for Turkey and calculate the relevant losses in Table 5 and compare them with respect to Turkey's GDP and reserves.

Figure 5. Actual revenues, neutral and optimistic forecasts (in billion USD)

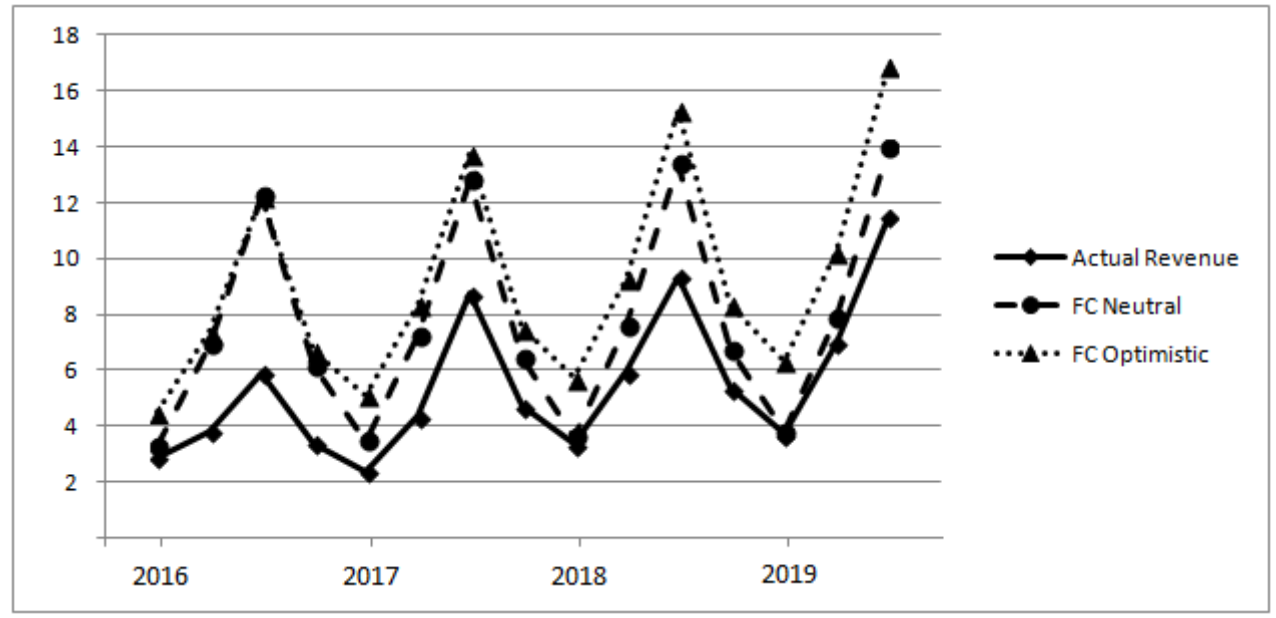

Based on the predictions, potential loss for Turkey is estimated to be between 33.1 up to 55.3 billion USD for the last three year period under the assumption that the attacks and the coup attempt did not take place. To pinpoint the impact of such a loss, we compare it with the most recent annual GDP and reserves of Turkey. Worldbank (2019) states that Turkey's GDP for 2018 was 771.35 billion USD. The loss during the three year period stands for $4.3-7.2 \%$ percent of the latest annual GDP. Such percentages sum up to the typical annual average GDP growth of Turkey and therefore are too large to be underestimated. For a comparison with the reserves, we utilize the data from TCMB (2019) that provide the most recent reserves information of 104.81 billion USD as of November, 2019. The three year tourism loss corresponds to 31.6$52.8 \%$ of current reserves of Turkey. In terms of national economic sustainability, such a loss is of utmost significance for Turkey who has accumulated a maximum reserves amount of around 150 billion USD in the past. Had Turkey been able to 
EFFECTS OF TERRORISM AND POLITICAL INSTABILITY ON TOURIST BEHAVIOR ...

obtain and retain the possible 55.3 billion USD, the Turkish reserves would have reached its all time highest value of 160.11 billion USD.

Table 5. Turkey's potential loss based on forecasts (in billion USD)

\begin{tabular}{|l|c|c|c|c|c|}
\hline Quarter & Actual & Neutral FC & Optimistic FC & Neutral loss & Optimistic loss \\
\hline $2016 \mathrm{q} 1$ & 2.88 & 3.31 & 4.50 & 0.427 & 1.623 \\
\hline $2016 \mathrm{q} 2$ & 3.81 & 6.93 & 7.38 & 3.117 & 3.566 \\
\hline $2016 \mathrm{q} 3$ & 5.89 & 12.23 & 12.24 & 6.338 & 6.352 \\
\hline $2016 \mathrm{q} 4$ & 3.41 & 6.16 & 6.71 & 2.745 & 3.293 \\
\hline $2017 \mathrm{q} 1$ & 2.40 & 3.47 & 5.11 & 1.061 & 2.705 \\
\hline $2017 \mathrm{q} 2$ & 4.38 & 7.25 & 8.34 & 2.878 & 3.960 \\
\hline $2017 \mathrm{q} 3$ & 8.73 & 12.80 & 13.78 & 4.070 & 5.056 \\
\hline $2017 \mathrm{q} 4$ & 4.72 & 6.44 & 7.53 & 1.729 & 2.812 \\
\hline $2018 \mathrm{q} 1$ & 3.35 & 3.62 & 5.72 & 0.276 & 2.367 \\
\hline $2018 \mathrm{q} 2$ & 5.94 & 7.58 & 9.30 & 1.646 & 3.360 \\
\hline $2018 \mathrm{q} 3$ & 9.37 & 13.37 & 15.33 & 3.998 & 5.955 \\
\hline $2018 \mathrm{q} 4$ & 5.37 & 6.73 & 8.35 & 1.357 & 2.975 \\
\hline 2019q1 & 3.70 & 3.78 & 6.32 & 0.079 & 2.618 \\
\hline $2019 \mathrm{q} 2$ & 6.97 & 7.91 & 10.26 & 0.935 & 3.281 \\
\hline 2019q3 & 11.48 & 13.94 & 16.87 & 2.457 & 5.386 \\
\hline TOTAL & $\mathbf{8 2 . 4 1}$ & $\mathbf{1 1 5 . 5 2}$ & $\mathbf{1 3 7 . 7 2}$ & $\mathbf{3 3 . 1 1 2}$ & $\mathbf{5 5 . 3 1 1}$ \\
\hline
\end{tabular}

\section{Conclusion}

A shift in tourist behavior triggered by concerns of safety might mean disaster for a developing country whose economy relies heavily on tourism income. Turkey is a typical example. Having a history of political conflicts, successful and failed coups, a generous variety of ethnic, politic and religious groups prepared to arm in the blink of an eye, a risk of economic devastation is always at the door. In this study, we examined the adverse events including two attacks and a failed coup attempt which took place during 2016. 
It was evident that the Turkish tourism industry faced a structural change. There was statistical evidence of a break in national tourism incomes $\left(\mathrm{H}_{1}\right)$, most evident during the spring and summer periods of 2016. This structural break can be attributed to the 12 January attack with a lag of three to six months and the peak of the break was observed in the summer period which included the failed coup attempt and another attack in the busiest international airport of Turkey. The impact was also supported was $\mathrm{H}_{3}$, and the shift in tourism trend was statistically clear. The monetary loss of Turkey since the time sums up to an estimated 33.1 to 55.3 billion USD, standing for one-thirds to half of the current national reserves. This huge amount could have boosted the Turkish GDP by 4.3 to $7.2 \%$, a figure no country would be willing to reject.

Yet again, despite all the negative publicity caused by the conflicts, Turkish tourism managed to put things in order. During the four year period (11 quarters), tourism revenues presented an even sharper upward trend. A possible reason for this could be that foreign tourists perceived the conflicts as one-off incidents. The governmental actions in the aftermath were severe, even to the point where the regime had started to be defined as converging autocracy by the local and foreign media and politicians, still this attitude might have provided a reassurance to the potential visitors to Turkey. In short, Turkey got off lightly from a potentially hazardous period and shall not underestimate the economic risk that was evident. Preventive measures to pave the way for a safer, more peaceful and tolerant social environment for tourists and locals alike, political stability in both internal and external terms, utmost care and respect for natural and historical resources should be of the highest priority for Turkey since such improvements could boost the tourism potential for the country.

\section{References}

Afonso-Rodriguez J.A. (2017), Evaluating the dynamics and impact of terrorist attacks on tourism and economic growth for Turkey, "Journal of Policy Research in Tourism, Leisure and Events", vol. 9 no. 1, pp. 56-81.

Alvarez M. D., Campo S. (2014), The influence of political conflicts on country image and intention to visit. A study of Israel's image, "Tourism Management", vol. 40, pp. 70-78. 
Basil C., Saleh A.S., Anwar S. (2019), Terrorism and tourism demand. A case study of Lebanon, Turkey and Israel, "Current Issues in Tourism”, vol. 22 no. 1, pp. 50-70.

Brida J.G., Cortez-Jimenez I., Pulina M. (2016), Has the tourism-led growth hypothesis been validated? A literature review, "Current Issues in Tourism", vol. 19 no. 5, pp. 394-430.

Chow G.C. (1960), Tests of equality between sets of coefficients in two linear regressions, "Econometrica", vol. 28 no. 3, pp. 591-605.

Drakos K., Kutan A.M. (2003), Regional effects of terrorism on tourism in three Mediterranean countries, "Journal of Conflict Resolution", vol. 47 no. 5, pp. 621-641.

Enders W., Parise G. F., Sandler T. (1992), A time-series analysis of transnational terrorism. Trends and cycles, "Defense Economics", vol. 3 no. 4, pp. 305-320.

Ferbar Tratar L., Mojškerc B., Toman A. (2016), Demand forecasting with four-parameter exponential smoothing, "International Journal of Production Economics", vol. 181 part A, pp. 162-173.

Feridun M. (2011), Impact of terrorism on tourism in Turkey. Empirical evidence from Turkey, “Applied Economics", vol. 43 no. 24, pp. 3349-3354.

Gupta S., Clements B., Bhattacharya R., Chakravarti S. (2004), Fiscal consequences of armed conflict and terrorism in low- and middle-income countries, "European Journal of Political Economy”, vol. 20, pp. 403-421.

Kleinbaum D.G., Kupper L.L. (1978), Applied regression analysis and other multivariable methods, Duxbury Press, North Scituate, MA.

Liu A., Pratt S. (2017), Tourism's vulnerability and resilience to terrorism, "Tourism Management", vol. 60, pp. 404-417.

Llorca-Vivero R. (2008), Terrorism and international tourism. New evidence, "Defence and Peace Economics", vol. 19 no. 2, pp. 169-188.

Öcal N., Yildirim J. (2010), Regional effects of terrorism on economic growth in Turkey. A geographically weighted regression approach, "Journal of Peace Research", vol. 47 no. 4, pp. 477-489.

Paternoster R., Brame R., Mazerolle P., Piquero A. (1998), Using the correct statistical test for the equality of regression coefficients, "Criminology", vol. 36 no. 4, pp. 859-866.

Perles-Ribes J.F., Ramon-Rodriguez A.B., Moreno-Izquedro L., Marti M.T.T. (2018), Winners and losers in Arab uprisings. A Mediterranean tourism perspective, "Current Issues in Tourism", vol. 21 no. 16, pp. 1810-1829. 


\section{Onur KOYUNCU}

Saha S., Yap G. (2014), The moderation effects of political instability and terrorism on tourism development. A cross-country panel analysis, "Journal of Travel Research", vol. 53 no. 4, pp. 509-521.

Seabra C., Dolnicar S., Abrantes J.L., Kastenholz E. (2013), Heterogeneity in risk and safety perceptions of international tourists, "Tourism Management", vol. 36, pp. 502-510.

TCMB (2019), International reserves and exchange liquidity report, https://www.tcmb.gov.tr/wps/wcm/connect/264ced94-946c-4bbf-a394-

7333fa1ffe16/RT201911T.pdf?MOD=AJPERES\&CACHEID=ROOTWORKSPACE-

264ced94-946c-4bbf-a394-7333fa1ffe16-mZ69WvU [02.01.2019].

Worldbank (2019), https://data.worldbank.org/country/turkey [02.01.2019].

Yaya M.E. (2009), Terrorism and tourism. The case of Turkey, "Defence and Peace Economics", vol. 20 no. 6, pp. 477-497. 